\title{
Editorial note: Locating the humanistic within the study of religions
}

I took my first class in the history of religions at a Swedish university in the spring of 1990. Study within the discipline was at that time a profoundly humanistic endeavour. Teachers and students were principally interested in subjects on the borders of literature, arts, history, and philosophy. Keen interest was taken in, for example, Egyptian death symbolism, Zen absurdity, and Palaeolithic hunting magic. Mircea Eliade was still revered. Much has changed since then. Among the reasons for this are the new global religio-political situation, with 'fundamentalist' violence and 'the return of religions' in politics, varying intellectual trends in universities, and, at least in Sweden, changes affecting the student population's economic situation, general knowledge interests, and their overall motivation for studying religion (today future teachers dominate the history/study of religion lecture room).

The major reorientation that these changes have brought with them has admittedly resulted in several improvements, such as sharper demystifying, more critical perspectives on religious discourse, scholars (chiefly in Islamic studies) working more closely with journalists and state officials, and, perhaps, more scientifically rigid analyses thanks to a greater use of social-scientific methods. However, this reorientation brings with it certain concerns that are, I think, obvious for any historian/scholar of religions. Among these we should mention the limitation of the source material to chiefly contemporary cases, the tedious use of discourse analysis and sociological models, students' inclination towards studying 'their own' tradition and popular culture, the lack of (time for) interest in close analysis of languages and semiotic systems, the decline in philosophical ways of debating and not only a fading curiosity concerning historically unknown religions, but also a general decline in the students' sense that 'the past is a foreign country' (to use the title of David Lowenthal's famous book). An easy way to describe this reorientation is to claim that the humanistic element of the history/study of religions has shrunk. As a consequence, Swedish scholars of religions have occasionally discussed the nature of this humanistic element and disputed its merit within the general study of religion and culture. This special volume of Temenos is an outcome of these discussions. Before the reader, who has, I am sure, encountered similar discussions and debates in their own country, turns the pages of these contributions by Swedish historians of religions I would like, as an appetiser, to indicate the different 
locations within the scholarship process in which the humanistic essence may be uncovered.

First, we might identify the humanistic in the scholar's general knowledge interest. This is what historian Richard Schlatter had to say about this matter in the 1960s:

The job of the humanist scholar is to organize our huge inheritance of culture, to make the past available to the present, to make the whole of civilization available to men who necessarily live in one small corner for one little stretch of time, and finally to judge, as a critic, the actions of the present by the experience of the past. [...] He must sift the whole of man's culture again and again, reassessing, reinterpreting, rediscovering, translating into a modern idiom, making available the materials and the blueprints with which his contemporaries can build their own culture, bringing to the center of the stage that which a past generation has judged irrelevant but which is now again usable, sending into storage that which has become, for the moment, too familiar and too habitual to stir our imagination, preserving it for a posterity to which it will once more seem fresh. The humanist does all this by the exercise of exact scholarship. He must have the erudition of the historian, the critical abilities of the philosopher, the objectivity of the scientist, and the imagination of all three. (Schlatter 1963, vii)

Schlatter's plea for a humanistic scholarship intentionally and directly contributing to cultural and political issues would probably gain few supporters in academia (despite the huge success of Norman Fairclough's 'critical discourse analysis', which explicitly shares his aims). Most scholars would surely agree that it should not be our objective either to produce cultural visions, ideologies, and ethical standards or to create and evaluate art. One might ask, however, given that it is considered worthwhile to supply facts and theories for government bodies, diplomatic reports, law enforcement assessments, and journalism why we should not aim also to contribute to philosophical problems, artistic designs, literary essays, new views of life, and palliative meditations in the manner of earlier generations (one thinks here of Max Müller, Söderblom, Frazer, and Eliade). It might even be the case that the history/study of religions would aid progress (to consciously use a vague notion) more efficiently if we did not produce knowledge relevant to the contemporary socio-political condition and instead clung to knowledge that was for the most part irrelevant for society yet relevant for 
culture. Perhaps people living amidst today's capitalist whirlwind of work, commodities, and money, 'find their ways home' more with the help of Native American mythology than they do when they have more information about the religio-political situation in the Middle East. This does not have to be an argument for escapism, but, as R. J. Reilly put it in referring to Tolkien's fantasy literature, 'a time to regroup one's forces for the next day's battle $(1969,147)^{\prime}$.

This leads us in any case to the most basic question: how do we justify our work? Has humanism as an ideological movement anything to do with it? For example, having read Bruce Lincoln's shrewd analysis in Religion, Empire, Torture (2007) of why American soldiers humiliated the Abu Ghraib prisoners, which, instead of portraying them as outright bastards, shows that, in dehumanising prisoners with the aid of a perverse kind of theatre, they tried desperately to persuade themselves that American propaganda was trustworthy, the reader surely receives an injection of humanistic sensibility. Is this what a humanistic study (though Lincoln himself would sternly reject that term as naive) is all about? There have been many scholars, however, driven by deeply anti-humanistic sentiments who have contributed profoundly to the humanistic study of religions.

Is a humanist perhaps interested in something other than man as citizen? Phenomena that are not characteristic of the regular functioning of a society, such as madness, masturbation, solitary prayer, art made solely for one self, the work of unique genius, and mysticism remain important objects of study for the humanities. Is this because we are primarily interested in humans as cultural creatures and not as social beings?

An alternative might be to look for the humanistic dimension in the philosophy of science, but does the humanistic enterprise rest on different philosophical foundations than the social and natural sciences? Terms such as methodological empathy and Verstehen seem opposed to the critical nature of science, but what exactly does 'critical' mean? Might it be more important to have a sympathetic approach to the object, at least if the phenomenon has been marginalised and misrepresented throughout history? Such a humanistic project seems to presuppose the existence of human nature: after all, if we want to talk about 'oppression', 'exploration', or 'alienation', do these concepts not imply that we can compare the existing human being with an ideal and potential human being?

Perhaps, then, the essence of the humanities has to do with methodology. Is it against the spirit of the humanities to do questionnaires? Do humanist scholars analyse texts differently from others? What of the significance of 
'privileged details', once argued by Carlo Ginzburg as the typical humanistic object? Should a talented scholar of the humanities be able to predict the downfall of American civilisation by the shape of a doorknob, as Adorno once did? Interpretation may have a role in every pursuit of knowledge. It might, however, be argued that the study of the metal in a Volkswagen (and the metallurgic process and the specific metal composition used in its production) is not part of the humanities, but that the study of its colour and style is. The reason for this is simply that colour and style, in contrast to the physical aspect of a thing, need to be interpreted.

It could also be the case that a humanist methodology is reflected in a special style of writing. Is not the ability to vividly re-describe a human situation, to express an accomplished sensibility about the emotions and thought of a group of people, as well as having an eye for details and patterns, a sine que non for the humanist? Is it not possible to judge whether a scholar has a profound knowledge of a cultural situation by the scholar's use of adjectives (the people in a photo, for example, express either 'wrath' or 'remorse')?

Finally, we should ask ourselves if there is something unique about which the humanities are theorising. The obsession with thinking within the fashionable cognitive sciences is a consequence of the diminishing role of the humanities, but are we not in need of more heart than head research? In War's Unwomanly Face the winner of the 2015 Nobel Prize for literature Svetlana Alexievich states: 'I'm not interested in events in themselves - I am aiming at the emotional events $(2012,20)$. ' The mission for the humanities might then be 'to see history as changes in sensibilities and style or, more, how different classes of people mobilized their emotional energies and adopted different moral postures $(1962,440)^{\prime}$, to use a phrase from Daniel Bell's The End of Ideology. Wherever we are inclined to locate what is humanistic in scholarly work, I am convinced that the questions about the relationships between the humanities, the social and natural sciences, and the cultural and political spheres of society are in urgent need of some contemporary rejoinders.

Stefan Arvidsson

Guest Editor 


\section{Aleksievič, Svetlana Aleksandrovna}

2012 Kriget har inget kvinnligt ansikte: en utopis röster. Stockholm: Ersatz.

\section{Bell, Daniel}

1962 The end of ideology: on the exhaustion of political ideas in the fifties. Cambridge, mass.: Harvard university press.

\section{Lincoln, Bruce}

2007 Religion, empire, and torture: the case of Achaemenian Persia, with a postscript on Abu Ghraib. Chicago: University of Chicago Press.

\section{Reilly, R.J.}

1969 Tolkien and the Fairy-Story - Isaacs, Neil D. \& Rose A. Zimbardo (eds) Tolkien and the Critics. Essays on J. R. R. Tolkien's The Lord of the Rings, 128-50. London: University of Notre Dame Press.

\section{Richard Schlatter}

1963 Introduction to the series - Holbrook, Clyde Amos, Religion, a humanistic field. Englewood Cliffs: Prentice-Hall. 
